\title{
Evaluation of the role of lie in daily life and Turkish tale type Keloğlan/The Bald-boy in the frame of Other- directedness schema domain ${ }^{1}$
}

\author{
Özlem Demren ${ }^{2}$ \\ Bahar Köse Karaca ${ }^{3}$ \\ Çağdaş Demren ${ }^{4}$
}

\begin{abstract}
Tales as an oral narratives gives us some ideas about the perceptions and attitudes of the people in a society. In this paper, we try to get your attention to the Keloğlan as a Turkish tale type who gives us some ideas about the psychological motivations and perceptions in Turkish culture. The Turkish tale hero Keloğlan is a timeless/fitting all-time character who gives clues for today with his personality from past narratives to the present. In fact, fairy tales set boundaries and offer acceptable models. Actually Keloğlan isn't really an ideal type but at the end of the tales, we come across with him as a type of winner. He always behaves against obstacles and inequity and he returns an ideal type. Lie is seen as a sympathetic trick in the Keloğlan tales. Keloğlan's lies and tricks are ignored by the society to the extent that he opposes injustice. Based on the Schema theory, we can say that the "other-directedness" schema domain is used in the tales of Keloğlan frequently, but in a way, related with lie. Keloğlan uses lie or manupilation for the reason of "approval seeking", but as a way of defence against to the "self-subjugation" and "self-sacrifice". In a sense, Keloğlan, as a Turkish tale type, shows us another aspect of society's approval mechanism.
\end{abstract}

Keywords: Tales of Keloğlan; lie; tricks; other-directedness.

\footnotetext{
${ }^{1}$ This paper is extended version of the presented paper in the "Interim Conference Of The International Society For Folk Narrative Research (ISFNR)-2015" at Hacettepe University in Ankara, Turkey.

2 Assist. Prof. Dr., Sivas Cumhuriyet University, Faculty of Literature, Department of Turkish Folklore, odemren@,cumhuriyet.edu.tr, (iD) 0000-0002-8924-5367

3 Assist. Prof. Dr., İstanbul Rumeli University, Faculty of Economics, Administrative And Social Sciences, Psychology Department, pskdr.baharkose@gmail.com, (iD) 0000-0001-5316-6985

4 Assoc. Prof. Dr., Sivas Cumhuriyet University, Faculty of Literature, Anthropology Department, cdemren@,cumhuriyet.edu.tr, (iD) $\underline{\text { 0000-0003-2246-7560 }}$
} 
Demren, Ö., Köse Karaca, B., \& Demren, C.. (2020). Evaluation of the role of lie in daily life and Turkish tale type Keloğlan/The Bald-boy in the frame of Other-directedness schema domain. Journal of Human Sciences, 17(4), 967-973. doi:10.14687/ihs.v17i4.6065

\section{Introduction}

Lie is one of the indispensable components in daily life of human. It can be said that there is no person who does not lie; therefore, there is no culture where people does not lie. Lie is one of the deepest mystery of human psychology; it has a close relationship with daily life and the cultural process where is existed. Although it is a human universal, that is, a common phenomenon that all people say and exhibit, its context or meaning in each society is different; these differences make the phenomenon of lies unique to culture as well as universal. While human makes lie a part of his/her psychology, at the same time makes it a part of his/her community. Lie has a very complex quality in interpersonal interaction as a psycho-dynamic and social process. It definitely resists mono-causal explanations. Lie is one of the founding elements of human socialization in daily life. Therefore in many moments of daily life it can arise with paradoxical reactions and reasons that can be contradicted with each other or can be encountered by behaviors.

Lie, includes a psychodynamic and social process, has different connotations in different societies and it is located in different contexts, which plays different roles in human relations and interactions. Probity and telling the truth are approved behaviours in many society, and lie generally is percepted adversely as morally. Truth and lie exist together in human life and they can be definable as to each other. This is a paradoxical process which shows us that without lie it could be difficult to define what the truth is (Van Dongen and Fainzang, 2002, p.85).

The paradoxical dimension of lie which is both attractive and precarious for human being could be confusing just as the situation of philosophers, anthropologist, psychologists, or other researchers. Many philosopher, think about on this paradoxical process look for a pertinant reply. For example, puritanical moralist philosopher Augustinus, seperates the lie phenomenon into different categories like, hurtful lies make somebody felt downtrodden or lies which is good for someone, but bad for another. Agustinus says that the truh is related with god so there is no lie which is forgivable even under the situation of a dilemma (Augustinus, 1998, p.39-43).

According to anothor profound thinker Francis Bacon, the virtue of mind emerges with truth, and he says that momentary lies pass through human mind is not as dangerous as the lies permanent in the mind. Because, permanent lies make much more harmful effect on the mind and morality (Bacon, 1998, p.44-46). Immanuel Kant however, interprets the topic in a secular frame. Kant says that the meaning of probity comes from being honest with own self that it is also a responsibility to others. And if one suffers from other person's honesty, this could be only an accidental encounter (Kant, 1998, p.47-51). Philosopher Henry Sidwick approaches to the topic relatively and says that there is no definite indication about what lie includes. And according to him, people would say the truth even they shouldn't in some situation (Sidgwick, 1998, p.52-54). Arguments of philosophers on lie show us that the debate on lie, morality and human behaviours are ongoing.

On the other hand, there are differences about perception of lie phenomenon in different societies. Antropologists show us the role of lie in daily routines of different societies. For example in a Greek village, lie has a vital importance. In this village, parents have a different method to teach their children how they understand if somebody lies. Parents tell lie to their children intentionaly, so the children try to learn catch the lie (Barnes, 1994, p.2, 74). According to another research, in a village in Mexico, especially to reach the daily information or understand some restrictions related to lie or manipulation have an important role. In Peru among the Sharanahua people lie has another role. In the society, to save the good relations with relatives, the truth is suppressed in some situations,. For example, meat has vital importance in this society and Sharanahua people when try to hide the quantity of meat from hunting, they manupilate the others. This situation is percepted unexeptional to save the good relations among relatives (Barnes, 1994, p.68-70). According to another example about perception of lie in Lebanon among Beit-Ahmads in some situations especially about family honour truth is suppressed. If truth causes some bad effects on the hierarchy and honour of someone, lie is unexeptional and sometimes shared collectively (Gilsenan, 
Demren, Ö., Köse Karaca, B., \& Demren, C.. (2020). Evaluation of the role of lie in daily life and Turkish tale type Keloğlan/The Bald-boy in the frame of Other-directedness schema domain. Journal of Human Sciences, 17(4), 967-973. doi:10.14687/ihs.v17i4.6065

1998, p.101-108). Lie can be used as a strategic or tactical tool in in-group or non-group relationships; in fact, it is often the case.

While different cultures have different motivations to tell lie, it is not known what kind of perception mechanism is effective on the act. At this point, we want to look upon the general attitudes in Turkish culture through the oral narratives. The Turkish tale type of Keloğlan gives us some hints about the topic and interpretating the processes behind the behavior, we get some help from the cognitive-behaviorist approach of Schema Theory.

\section{2. "Other-Directedness" in Turkish Culture and Schema Theory}

Schema Theory is one of the psychotherapeutic approaches that used in order to define thoughts, beliefs and rules arising from childhood, the concept of "Early Maladaptive Schemas" is used. It is defined as "stable and enduring themes that developed during childhood are elaborated throughout an individual's lifetime". According to Schema Theory people's perceptions and attitudes effected from schemas in their mind (Young, 1999, p.9). Related studies says that, there are eighteen schemas under five schema domains. These five schema domains are a) Disconnection and rejection; b) Impaired autonomy and performance; c) Impaired limits; d) Overvigilance and inhibition; and e) Other-directedness (Young, Klosko and Weishaar, 2003, p.14-17).

The current studies conducted with Turkish population related to Schema Theory revealed that "other-directedness" is one of the most used "schema domain" among other five schema domains and which is compromised from "approval-seeking", "self-sacrifice", and "selfsubjugation" (e.g, Atalay, Akbaş, Zahmacioğlu, Kılıç and Göktuna, 2013; Gök, 2012; Köse, 2009; Köse Karaca, 2014; Sarıtaş and Gençöz, 2011; Soygüt, Karaosmanoğlu and Çakır, 2009; Ünal, 2012). Other-directedness schema domain is based on "an excessive focus on the desires, feelings, and responses of others, at the expense of one's own needs - in order to gain love and approval, maintain one's sense of connection, or avoid retaliation". Roots of this domain arise from "conditional acceptance: children must suppress important aspects of themselves in order to gain love, attention, and approval. In many such families, the parents' emotional needs and desires - or social acceptance and status - are valued more than the unique needs and feelings of child". Domain of other-directedness involves the schemas of subjugation based on "excessive surrendering of control to others because one feels coerced - usually to avoid anger, retaliation, or abandonment"; self-sacrifice related to "excessive focus on voluntarily meeting the needs of others in daily situations, at the expense of one's own gratification"; and approval-seeking based on "excessive emphasis on gaining approval, recognition or attention from other people or fitting in, at the expense of developing a secure and true sense of self" (Young et al., 2003, p.14-17).

This knowledge draw attention to the relationship between other-directedness and Turkish culture. In this kind of a society, in order to take acceptance, love and attention, people believe that they have to behave through social norms and rules. Therefore, while these people draw attention to stories related to badness of lying; they have the problem to confess their act of lying paradoxically since they do not tolerate the risk of rejection (Köse Karaca, 2014). We can see similar findings also in an article written by Emine Gürsoy Naskali, in the "Book of Lie" (2015) It is stated in this study that the reason of lying has a broad context in the stories of research group which consists two hundred-ninety-five young people between the age of ten to eighteen. The reasons of lie encountered in these stories are classified under three titles; namely, lying to suppress the delinquency, lying for what is wanted, and lying for defense. In this research, it is emphasized that the main reason of lying mostly the risk or fear of rejection (Gürsoy Naskali, 2015, p.137-138).

In this sense, the idea of the subsistence of a relationship between "other directednes" schema domain and Turkish culture, make arise another viewpoint to understand perceptions and attitudes about lie in Turkish culture. Based on this viewpoint, we search the examples of Turkish oral narratives about the motif and try to understand how "lie" appears in oral narratives as manupilation or trick. In this sence, we could catch some hints about indicated relations between 
Demren, Ö., Köse Karaca, B., \& Demren, C.. (2020). Evaluation of the role of lie in daily life and Turkish tale type Keloğlan/The Bald-boy in the frame of Other-directedness schema domain. Journal of Human Sciences, 17(4), 967-973. doi:10.14687/ihs.v17i4.6065

schemas and narratives of any culture. When we interprate the lie phenomenon in the frame of Schema Theory, it could be said that, what cause the lie in daily routines, or another word, the reason of lie is the main point. Thus, in this paper, we try to get your attention to different approach of schema theory to lie phenomenon and we made some further research depending on our suggestion related to other-directedness and lying in Turkish oral narratives.

\section{Keloğlan/The Bald-Boy as a Turkish Tale Type and "His Lie"}

Oral narratives, as one of the important parts of tradition, reflects the mind and perceptions of the people living in a society and they are formed by various motifs which is "the smallest element of nartation" (Alptekin, 1997, p.297), belong to the culture. When we review oral narratives, we can find some aspects of lie or we can find several types related with lie as motif which is showed in severel motif indexes ${ }^{5}$. According to our research, Turkish tales could give us lots of material about the motif of lie or the types related with lying. When we review the examples we could see the cause of lie or the reason of lying has an importance in the narrative frame in some tales. The main character of the tale or other types in the tale could be the type of a lier or manupilator. In the tales, which reflect lots of emotion and reality about life, the listeners are wanted to feel emphaty with the main character of the tale. If the main character of the narrative lies, there is always a comprehensible reason of character that because the main character should always be the ideal type and the narrative should improve in this frame, but the same situation isn't valid for the other characters related with lie (Dursun, 2015, p.5-6). Concerning with the morally accaptable narrative, it is important to be an idel type in order to the approvel of interested listeners. In another words, the main character of the tale should have the acceptible reasons and ideal attributions from avoiding the risk of rejection.

For example, one of the tale type of Turkish tales Keloğlan ${ }^{6}$, name of a poor orphan boy who is the hero of many tales and he has a remarkable character with his tricks (Dursun, 2015, p.6). Keloğlan is a cute, sly boy, most of the time he is looked down and pushed around but he is still a hero fights against injustice. He defeats his poverty and unhappiness with his tricks and intelligence. Keloğlan is not an ideal hero type. Sometimes he has bad behaviours and not obey the rules. But he finally finds the right path. He shows insidious and clever resistance to injustice and finishes business with his own way. "Sultans, and the world's beauty is saved by his tricks; Keloğlan becomes the sultan and marries with the daughter of sultan". He handles the most complex events with his reasoning, intelligence and sympathetic tricks. "These qualities make his baldness even tolerable" (Aslan, 2001, p.34).

Keloğlan collects the some characteristics of Turkish people on his own. He trusts reasoning and luck helps. He has humorous way of perception and behaviour. Keloğlan, as a type is parallel with tricster archetype (Şimşek, 2017, p.52-53). Most of the time in tales, Keloğlan use the way of manupilation -like telling lie or deceiving- to overcome the obstacles, and he always has an acceptible reason why he manipulates the other characters who try to make Keloğlan overhelmed. Manupilating the other unfair characters, Keloğlan try to save the life of his own or some others who is innocent; try to cure an injustice; try to raise dignity or try to prove himself. These reasons even he lies or manupilates the others- always find a place in the realism of daily life to be an approved ideal type in the society (Dursun, 2015, p.6-33). In most tales he returns different and more desirable character with his tricks. He achives his goals in a duality of good and bad, true or false like in the life of real people (Şimşek, 2017, p.55).

\footnotetext{
5 See the "Motif Index of Folk Literature" prepared by Thompson (1932-1936, revised and expanded 1955-1958); "Typen Türkishcher Volksmärchen" prepared by Eberhard and Boratav (1953); and "The Types of International Folktales" (2004), prepared by Uther, named "The ATU System" based on the system of Aarne and Thompson.

"See the "Tales of Keloğlan" (Alangu, 2016).
} 
Demren, Ö., Köse Karaca, B., \& Demren, C.. (2020). Evaluation of the role of lie in daily life and Turkish tale type Keloğlan/The Bald-boy in the frame of Other-directedness schema domain. Journal of Human Sciences, 17(4), 967-973. doi:10.14687/ihs.v17i4.6065

In folk tales, that have their own rules, time, space and plot are the basic parts gain functionality through character typology. The plot in folktales develops around the hero of the fairy-tale type encountering a problem and waiting for the solution of this problem (Ozan, 2011, p.72). Keloğlan a symbolic type of Turkish tales. He appears as a type who "reveals his own existence" (Önal, 2013, p.302, 307) to overcome the "tricks of others" and their difficulties. Keloğlan tales take place in a realistic world, between realistic people and events. Unlike the other fairy-tale heroes, Keloğlan comes from the lower status and he rises as the aresult of "coincidences, his own compulsions and revolts against injustices" (Bekki, 2004, p.99). "The only weapon of Keloğlan against his enemies is his mind, intelligence and cunning". The aim of Keloğlan in fairy tales is to achieve success and power (Alptekin, 2004, p.98).

\section{Discussion and Conclusion}

Turkish fairy tale hero Keloğlan is a timeless / fitting all times character that gives clues for today with his personality from past narratives to the present. In fact, tales set boundaries and offer acceptable models. Obstacles, despair, intrigues, fears that we encounter in fairy tales becomes solvable by using methods like patience, compromise, using your mind, cunning and deceit. In fairy tales, the bad loses, the good wins; Keloğlan, the symbolic type of Turkish tales that can be deceitful, sometimes liar and cunning, is a character that manages to stay in the balance between good and bad. In fact, resorting to lie and deceit is an act that is excluded by the society. The lie and deceit that we encounter in the Keloğlan tales, that is the cheating of the Keloğlan, are presented to us in a sympathetic way. Is this the shadow forth of such a message in the Keloğlan narratives?: "Even if you're going to cheat, keep it fit; there is a way of doing that". This suggestion can be a clue that lie and deception, that is, negative behavior, should be stuck within acceptable limits. So what are society's acceptable limits to cheating and cunning? How does Keloğlan, who is bald, orphan, poor, cheater and lier, stays in balance with so many shortcomings and still gets approval from others? The trick should be clever; it should reflect quick wit; may contain jokes; it must find a solution to the problem and ensure that power is finally obtained; that is, it must balance between the best behavior and the worst, the one to be excluded, and power it. Here, Keloğlan gets approval from others by staying in balance in his behavior at that border. Well, who are the others according to Keloğlan? Everyone who confronts the keloğlan with a problem; and everyone who will approve of the Keloğlan positively after he has won the power struggle, that is, the people who need power in the society, and the listeners of these narratives are among the others. Trying to understand the Keloğlan's way of dealing with difficulties can give us a clue of what? Understanding the Keloğlan gives us clues about how lie and cheating are perceived by our society during the power struggle. A message is also presented like this: You don't have to be perfect, you can still succeed; you can rise from the bottom to the top and gain power, you can reach wealth from poverty, you can rise from disrepute to dignity, still you can find a way to overcome the adversity.

Keloğlan tales continue to be passed down from generation to generation through those who tell, read and listen to it. Accompanying us through narratives, Keloğlan is an archetype of Turkish society with a tendency of other-directedness, psychologically. The other-directedness tendency of Turkish society shows itself best in adherence to social norms. In Turkish culture, "approval of others" is important. The place of the individual, in the eyes of others in the society is controlled by social norms. Social norms determine what you will do and how you will behave in the society. Behaviors that are exhibited outside of social norms can lead to punishments ranging from mild to severe such as condemnation and exclusion (see Örnek, 1995). In Turkish society, other-directedness gain its power from here. Social norms is effective in shaping the behavior and motivation of individuals; in a sense, social norms guide the behavior of individuals. Because, in order to be approved by the society, it is necessary to exhibit behaviors that are approved. So why does Keloğlan not be excluded and even get the approval of others even if he 
Demren, Ö., Köse Karaca, B., \& Demren, C.. (2020). Evaluation of the role of lie in daily life and Turkish tale type Keloğlan/The Bald-boy in the frame of Other-directedness schema domain. Journal of Human Sciences, 17(4), 967-973. doi:10.14687/ihs.v17i4.6065

behaves negatively, in a way? Because the winner in the power struggle gets the approval of others. Here, as a result of the interest in power and strength, Keloğlan uses his mind, closes his deficiencies and solves the problem, seizes the power and gets the approval of the others, and the way he applies for all these is considered to be allowable. As a result, it can be said that in Keloğlan tales, which are one of the important elements of the Turkish narrative tradition, otherdirectedness appears as a way of reaching power.

\section{References}

Alangu, T. (2016). Keloğlan masalları. İstanbul: Yapı Kredi Yayınları.

Alptekin, A. B. (1997). Halk hikayelerinin motif yapısı. Ankara: Akçağ.

Alptekin, A. B. (2004). "Keloğlan". Türk dünyası edebiyat kavramları ve terimleri ansiklopedik sözlüğü. Ankara: AKDTYK Atatürk Kültür Merkezi, s. 97-99.

Aslan, E. (2001). Masal araştırmaları ve Korkak Ali masalı üzerine bir inceleme. Milli Folklor, (52): 33-45.

Atalay, H., N. B. Akbaş, O. Zahmacıoğlu, E. Z. Kılıç \& Z. Göktuna (2013). Are early maladaptive schemas, temperament and character dimensions correlated?, Open Journal of Psychiatry, 3(2), p. 206-213.

Augustinus (1998). Yalan üzerine. Cogito - Yalan. İstanbul: Yap1 Kredi Yayınları, (16): 39-43.

Bacon, F. (1998). Hakikat üzerine. Cogito - Yalan. İstanbul: Yap1 Kredi Yayınlar1, (16): 44-46.

Barnes, J. A. (1994). A pack of lies - Towards a sociology of lying. Cambridge: Cambridge University Press.

Bekki, S. (2004). "Keloğlan masalları". Türk dünyası edebiyat kavramları ve terimleri ansiklopedik sözlügü. Ankara: AKDTYK Atatürk Kültür Merkezi, s.99.

Dursun, A. (2015). Keloğlan masallarında yalan ve hilenin işlevi. Yalan kitabı (Ed. Emine Gürsoy Naskali), İstanbul: Kitabevi, s. 5-35.

Eberhard, W. \& Boratav, P. N. (1953). Typen Türkishcher volksmärchen. Wiesbaden: Franz Steiner Verlag GMBH.

Gilsenan, M. (1998). Yalan, şeref ve çelişki. Cogito - Yalan. İstanbul: Yapı Kredi Yayınları, (16): 93125.

Gök, A. C. (2012). Associated factors of psychological well-being: Early maladaptive schemas, schema coping processes, and parenting styles. Unpublished Master's Thesis, Middle East Technical University, Ankara, Turkey.

Gürsoy Naskali, E. (2015). Yalan hikâyeleri. Yalan kitabı (Ed. Emine Gürsoy Naskali), İstanbul: Kitabevi Yayınlan1, s. 137-252.

Kant, I. (1998). İnsanseverlikten ötürü yalan söylemek konusunda bir sözümona hak üzerine. Cogito - Yalan, 16, İstanbul: Yapı Kredi Yayınları, s. 47-51.

Köse, B. (2009). Early maladaptive schemas and well- being with the moderator effect of balanced integration differentiation model. Unpublished Master's Thesis. Middle East Technical University, Ankara, Turkey.

Köse Karaca, B. (2014). The effects of Young schema domains, Young maladaptive coping styles, and Young parenting styles on working alliance among supervisors, therapists, and the clients. Unpublished Dissertation, Middle East Technical University, Ankara, Turkey.

Ozan, M. (2011). Geçiş ritüelleri ve halk masalları. Millî Folklor, (91): 72-84.

Önal, M. N. (2013), Masalların sembolik dili. Türk halk edebiyatı incelemeleri, Saim Sakaoğlu armağanı, (Ed. Metin Ergun), Ankara: Türk Kültürünü Araştırma Enstitüsü Yayınlanı, s. 299-310.

Örnek, S. V. (1995). Türk halkbilimi, Ankara: Kültür Bakanlığ1 Yayınları.

Sarıtaş, D., \& Gençöz, T. (2011). Psychometric properties of "Young Schema Questionnaire-Short Form 3" in a Turkish adolescent sample. Journal of Cognitive Behavioral Psychotherapies, 11(1): 83-96. 
Demren, Ö., Köse Karaca, B., \& Demren, C.. (2020). Evaluation of the role of lie in daily life and Turkish tale type Keloğlan/The Bald-boy in the frame of Other-directedness schema domain. Journal of Human Sciences, 17(4), 967-973. doi:10.14687/ihs.v17i4.6065

Sidgwick, H. (1998). Ödevlerin sinıflandırılması: Doğruluk. Cogito - Yalan. İstanbul: Yap1 Kredi Yayınlar1, (16): 52-54.

Soygüt, G., Karaosmanoğlu, A. \& Çakır, Z. (2009). Erken dönem uyumsuz şemaların değerlendirilmesi: Young Şema Ölçeği Kısa Form-3'ün psikometrik özelliklerine ilişkin bir inceleme. Türk Psikiyatri Dergisi, 20(1): 75-84.

Şimşek, E. (2017). Türk masallarının milli tipi: Keloğlan. Akra Kültür Sanat ve Edebiyat Dergisi, (11): 41-57.

Thompson, S. (1955-1958). Motif-index of folk-literature: A classification of narrative elements in folktales, ballads, myths, fables, mediaeval romances, exempla, fabliaux, jest-books, and local legends. (Revised and enlarged edition), Bloomington: Indiana University Press. Accessed: https://www.ualberta.ca/ urban/Projects/English/Motif_Index.htm

26.12.2015,

Uther, H.-J. (2004). The types of international folktales: A clasification and bibliography based on the system of Anti Aarne and Stith Thompson. Vol. 1-3. Helsinki: Academiz Scientiarum Fennica. Accessed: 26.12.2015 https://www.ualberta.ca/ urban/Projects/English/Content/Tale_Types.htm\#atu

Ünal, B. (2012). Early maladaptive schemas and well-being: Importance of parenting styles and other psychological resources. Unpublished Master's Thesis. Middle East Technical University, Ankara, Turkey.

Van Dongen, E. \& Fainzang, S. (2002). Lying, misery and illness: Towards a medical anthropology of the lie. Anthropology \& Medicine, 9(2): 85-95.

Young, J. E. (1999). Cognitive therapy for personality disorders: A schema focused approach. Sarasota FL: Professional Resource Press.

Young J. E., Klosko J. S., \& Weishaar, M. E. (2003). Schema therapy: A practitioner's guide. New York: The Guilford Press. 